\title{
Diversification of Cassava Flour in the Manufacture of Gluten-Free Flakes Enriched with Dietary Fibers from Virgin Coconut Oil Waste Flour
}

\author{
Diana Widiastuti, Eka Herlina, Ade Heri Mulyati and Siti Warnasih \\ Department of Chemistry, Pakuan University, Bogor 16163, Indonesia
}

\begin{abstract}
Food diversification is a way to strengthen national food security, for example by reducing the dependence on wheat flour as a main raw material of various food products through the use of cassava flour. Cassava flour, a rich source of carbohydrates, can be used in the making of flakes. In this study, the Virgin coconut oil (VCO) waste flour was added in cassava flour to produce gluten-free cassava flour flakes with high dietary fiber contents. The six different formulas of flakes were used in this study with addition of $0 \%$ (control), $10 \%, 20 \%, 30 \%, 40 \%$ and $50 \%$ coconut waste flour, respectively. Then, the chemical and microbiological characteristics of the flakes were measured. Based on the proximate data, both flours have a good quality. The microbiological analysis shows cassava flour and coconut waste flour have good sanitation and food safety. Results showed that flakes with $80 \%$ cassava flour and $20 \%$ coconut waste flour are gluten-free and contain $2.52 \%$ water, $2.27 \%$ ash, $14.40 \%$ fat, $4.50 \%$ protein, $76.31 \%$ carbohydrate, $8.56 \%$ dietary fiber. Therefore, it can be said that cassava flour flakes can serve as gluten-free and rich dietary fiber ready-to-eat food.
\end{abstract}

Key words: Flakes, cassava flour, Virgin coconut oil waste flour, gluten-free, dietary fiber.

\section{Introduction}

Cassava (Manihot esculenta Crantz) is one of the tuber and cash crop. As a food crop, cassava is a source of carbohydrates for about 500 million people worldwide. Cassava production in Indonesia is largely used as food as much as $64 \%$, while the rest is used as raw material for the starch industry, fuel and feed [1]. Cassava flour is excellent for digestion, and its low cholesterol content can prevent certain diseases, including diabetes, heart disease and high blood pressure. Cassava flour is a good enough source of carbohydrates, because every $100 \mathrm{~g}$ of cassava contains $88.20 \mathrm{~g}$ of carbohydrates [2].

Cassava flour is made from cassava that has been dried, pulverized and sieved using a 100 mesh sieve [3]. To obtain good-quality flour, it is best to use newly harvested cassava and it should be processed

Corresponding author: Diana Widiastuti, lecturer, research field: food chemistry. into flour immediately. Moreover, cassava that is quite old which has a relatively low water content can also be used to produce more quantity of flour.

The cassava variety used in this study is manggi cassava. Long and steammed manggi cassava is sweet and contains hydrogen cyanide (HCN) $30 \mathrm{mg} / \mathrm{kg}$ (peeled), so it is suitable for consumption [4].

Various coconut meat processing industries to produce coconut milk and coconut oil leave some waste (coconut pulp). On the other hand, such coconut pulp waste has nutritional values and is high in dietary fiber which is good for health. Coconut pulp waste has so far been discarded or used as fodder with very low market price [5]. Coconut pulp can be processed into coconut flour, which can then be used as raw materials in the food industry. The expanded use of coconut pulp from fodder to foodstuff would be very economically beneficial for coconut growers and coconut-based food producers, as well as providing health and nutrition benefits for society [5]. 
Coconut waste from Virgin coconut oil (VCO) manufacture has a high content of dietary fibers. The microbiological analysis shows coconut flour has good levels of sanitation and food safety. Coconut waste flour can be used as a raw material or an ingredient in the manufacture of food products [6]. Researches on the use of coconut waste flour in processed food products need to be continued. The purpose of this study was to determine the best formula of cassava based flakes (Manihot esculenta Crantz), enriched with coconut waste dietary fiber and gluten-free.

\section{Materials and Methods}

Cassava (Manihot Esculenta Crantz) used in this study is Manggu variety from a plantation in Kaum Pandak, Bogor subdistrict, West Java, Indonesia. This study applies completely random design (CRD) with six treatments of cassava flour and coconut waste flour ratios.

\subsection{The Making of Cassava Flour}

Cassava's skin is removed, and then cassava is cleaned and shredded. The shredded cassava is dried until it reaches the maximum water content allowed and finally sieved at 60 mesh.

\subsection{The Making of Coconut Waste Flour}

At a ratio of $1: 8,1 \mathrm{~kg}$ of coconut pulp is added with water, boiled and left $40 \mathrm{~min}$ while being stirred. Next, coconut waste is pressed and dried at $50{ }^{\circ} \mathrm{C}$ before it is finally sieved at 60 mesh [5].

\subsection{The Making of Flakes}

In this study, cassava flakes are made with six different ratios of cassava flour and coconut waste flour in total $100 \mathrm{~g}, 15 \mathrm{~g}$ margarine, $15 \mathrm{~g}$ sugar, $12 \mathrm{~g}$ salt, $20 \mathrm{~g}$ coconut milk, $15 \mathrm{~g}$ skim milk and $50 \mathrm{~g}$ water. First, weigh all the ingredients according to the specified amounts, mix them all, add coconut milk little by little, and then add some warm water to the dough. Next, the dough, after it is shaped into a sausage-like piece, is steamed. When it is done, the dough is cooled and sliced for $2 \mathrm{~mm}$ into flakes. The flakes are then baked in the oven at $150{ }^{\circ} \mathrm{C}$ for $20 \mathrm{~min}$. The last step is the cooling of the flakes at $38{ }^{\circ} \mathrm{C}$ for $10 \mathrm{~min}$. The six different formulas of flakes made in this study are:

$\mathrm{F}_{1}: 100 \%$ cassava flour and $0 \%$ coconut waste flour (control);

$\mathrm{F}_{2}: 90 \%$ cassava flour and $10 \%$ coconut waste flour;

$\mathrm{F}_{3}: 80 \%$ cassava flour and $20 \%$ coconut waste flour;

$\mathrm{F}_{4}: 70 \%$ cassava flour and $30 \%$ coconut waste flour;

$\mathrm{F}_{5}: 60 \%$ cassava flour and $40 \%$ coconut waste flour;

$\mathrm{F}_{6}: 50 \%$ cassava flour and $50 \%$ coconut waste flour.

\subsection{The Measurement of Flake Characteristics}

Next, the flakes are characterized physically, chemically and microbiologically to determine water content [7], ash content [7], protein content [7], fat content [7], carbohydrate content [8], total dietary fiber (TDF) [9], mineral content ( $\mathrm{Ca}, \mathrm{Mg}, \mathrm{Na}, \mathrm{K}, \mathrm{Fe}$ ) [9], gluten [10], total plate count (TPC) [11], Escherichia coli [12], mold [13] and Bacillus Cereus [11]. A preference level test, including color, aroma, flavor and texture, involves 20 panelists.

\section{Results and Discussion}

\subsection{Characteristics of Cassava Flour and Coconut Waste Flour}

Color, taste and aroma are observed by using the senses. Cassava flour has $78.26 \%$ yield, and is white, fine and smells like typical cassava. While the coconut waste yield is $45.14 \%$, and it is white and a little fibrous with coconut aroma (Table 1). This is due to the removal of all cassava peels and the washing before the making process.

Water content of cassava flour and coconut waste flour is influenced by several factors during the drying process as well as before they are processed. The water content in foodstuff determines acceptability, freshness and durability of the foodstuff [14]. Water is 
Table 1 Characteristics of cassava flour and coconut waste flour.

\begin{tabular}{lll}
\hline Parameter & Cassava flour & Coconut waste flour \\
\hline Yield & $78.26 \%$ & $45.14 \%$ \\
Color & White & White \\
Texture & Fine & A little fibrous \\
Aroma & Cassava & Coconut \\
\hline
\end{tabular}

Table 2 Chemical and microbiological characteristics of cassava flour and coconut waste flour.

\begin{tabular}{llll}
\hline Parameter & Cassava flour & Coconut waste flour & SNI wheat flour [15] \\
\hline Water (\%) & 8.81 & 4.89 & Max. 14.50 \\
Ash (\%) & 0.39 & 0.16 & Max. 0.70 \\
Fat (\%) & 1.21 & 43.32 & - \\
Protein (\%) & 2.59 & 13.40 & Min. 7.00 \\
Carbohydrate (\%) & 87.00 & 38.23 & - \\
Dietary fiber (\%) & 23.98 & 32.81 & - \\
$\mathrm{K}(\mathrm{ppm})$ & $3,548.50$ & $3,368.23$ & - \\
$\mathrm{Na}(\mathrm{ppm})$ & 74.80 & 85.61 & - \\
$\mathrm{Fe}(\mathrm{ppm})$ & 460.25 & 75.10 & Min. 50.00 \\
$\mathrm{Ca}(\mathrm{ppm})$ & 213.84 & 267.38 & - \\
$\mathrm{Mg}(\mathrm{ppm})$ & 673.16 & $1,606.50$ & - \\
$\mathrm{Total} \mathrm{plate} \mathrm{count} \mathrm{(col/g)}$ & $7.10 \times 10^{2}$ & $5.50 \times 10^{2}$ & Max. $1 \times 10^{6}$ \\
E. coli $(\mathrm{col} / \mathrm{g}) *$ & $<3$ & $<3$ & Max. 10 \\
Mold $(\mathrm{col} / \mathrm{g})$ & 10 & 10 & Max. $1 \times 10^{4}$ \\
B. cereus (col/g) & 100 & 100 & Max. $1 \times 10^{4}$ \\
\hline
\end{tabular}

SNI: Indonesia National Standardization Agency; *: most probable number; -: no standard data.

an important component in foodstuff, since water may affect the appearance, texture and flavor of food. The ash content is the inorganic residue from incineration processes contained in the natural inorganic compounds, such as $\mathrm{K}, \mathrm{Ca}, \mathrm{Na}, \mathrm{Fe}, \mathrm{Mg}$ and $\mathrm{Mn}$. The higher the ash content in foodstuff, the higher levels of the minerals in it [14]. According to Kurzweilai [16], similar as carbohydrates, fat is a very important source of energy for the body, up to $9 \mathrm{kcal} / \mathrm{g}$. Protein is an essential nutrient for human body, because it serves as fuel in the body and also as a builder and a regulator [14]. As shown in Table 2, dietary fiber for cassava flour is $23.98 \%$ and $32.81 \%$ for coconut flour waste. The Food Standards Agency recommends that products that claim to be a source of dietary fiber should contain as much as 3-6 g/100 g. Dietary fiber has the benefit to improve the digestive system of the body and also to lose weight. Besides the amounts of TPC $(8.81 \%$ and $4.89 \%)$ and E. Coli (both $<3$ ), respectively, in casava flour and coconut waste flour, the water $(8.81 \%$ and $4.89 \%)$, ash $(0.39 \%$ and $0.16 \%)$, protein $(2.59 \%$ and $13.40 \%)$ and $\mathrm{Fe}$ contents also meet the requirements. Based on the data above, therefore, cassava flour and coconut waste can be used as sources of dietary fiber. The microbiological tests show that both coconut waste flours meet the requirements of Indonesia National Standardization Agency (SNI) [15].

\subsection{Characteristics of Flakes}

The cassava-based flake products are enriched with coconut waste and other ingredients with six different ratios of cassava flour with coconut waste flour formulas, using trial and error methods.

The organoleptic test involved 20 untrained panelists and was conducted to determine how big the consumer acceptance of the products. The organoleptic test includes color, aroma, flavor and 
crispness attributes. Data obtained on the organoleptic test were statistically analyzed using ANOVA Ragan fingerprint analysis with Duncan advanced test and Friedman's rank test with $95 \%$ confidence interval. The rating of the panelist's acceptance of the flakes with various formulations is listed in Tables 3 and 4.

The color rating tests show that the formulation does not significantly affect the color parameter at $95 \%$ confidence interval. There is no significant difference among the six flake formulas, because both cassava flour and coconut waste flour are white, and flakes use the same ingredients, such as margarine and skim milk and also the baking in the oven.

The aroma parameter indicates that $F_{1}$ is not significantly different from $\mathrm{F}_{3}, \mathrm{~F}_{5}$ and $\mathrm{F}_{6}$, but the four formulas are significantly different from $\mathrm{F}_{2}$ and $\mathrm{F}_{4}$. The aroma of cassava flour flakes with the addition of coconut waste is a typical aroma of coconuts.

The crispness parameter indicates that $F_{1}$ is not significantly different from $F_{2}, F_{3}, F_{4}$ and $F_{6}$, but the four formulas are significantly different from $F_{5}$. Crispness of flakes is heavily influenced by the water content of the flakes. The higher the water content the flakes have, the less crispy the flakes are. At $95 \%$ confidence interval, $F_{1}, F_{3}, F_{4}$ and $F_{5}$ are not significantly different, while $\mathrm{F}_{2}$ and $\mathrm{F}_{6}$ are significantly different from the other four formulas.

The flavor parameter shows that formulation highly determines panelists' preferrence at 95\% confidence interval. $F_{1}, F_{3}, F_{4}$ and $F_{5}$ are slightly different in flavor but they are significantly different from $\mathrm{F}_{2}$ and $\mathrm{F}_{6}$.

Rangking test result was given by 20 panelists. The preference ranges is in 1 to 5 , where 1 is for the most liked and 5 the most dislike. $\mathrm{F}_{3}$ has the lowest rate (2.35), followed by $F_{1}, F_{2}, F_{4}, F_{5}$ and $F_{6}$. Thus, flake with $80 \%$ cassava flour and $20 \%$ coconut waste flour $\left(\mathrm{F}_{3}\right)$ is the most preferred product by panelists (Table 5). $F_{3}$ is more preferred compared to $F_{1}$ (control), this shows that the addition of coconut waste flour to cassava flakes can enrich its flavor.

\subsection{Chemical and Microbiological Characteristics of Flakes}

The water content of $\mathrm{F}_{3}$ is not significantly different from that of $F_{1}$ which is $2.51 \%$. According to the SNI 01-3842-1995 [17], the maximum water content of instant cereal based complementary foods is $4 \%$. Besides, its contents of ash, fat, protein, carbohydrates, dietary fibers and minerals meet the national standards

Table 3 Statistics and rating tests of cassava and coconut waste flakes.

\begin{tabular}{lllll}
\hline \multirow{2}{*}{ Treatment } & \multicolumn{4}{c}{ Parameter } \\
\cline { 2 - 5 } & Color & Aroma & Crispness & Flavor \\
\hline $\mathrm{F}_{1}$ & $5.20^{\mathrm{a}}$ & $4.55^{\mathrm{a}}$ & $4.40^{\mathrm{a}}$ & $4.50^{\mathrm{a}}$ \\
$\mathrm{F}_{2}$ & $4.60^{\mathrm{a}}$ & $5.90^{\mathrm{b}}$ & $4.90^{\mathrm{a}}$ & $5.50^{\mathrm{b}}$ \\
$\mathrm{F}_{3}$ & $5.15^{\mathrm{a}}$ & $4.70^{\mathrm{a}}$ & $4.45^{\mathrm{a}}$ & $4.55^{\mathrm{a}}$ \\
$\mathrm{F}_{4}$ & $5.10^{\mathrm{a}}$ & $5.75^{\mathrm{b}}$ & $5.05^{\mathrm{ab}}$ & $4.55^{\mathrm{a}}$ \\
$\mathrm{F}_{5}$ & $5.25^{\mathrm{a}}$ & $4.60^{\mathrm{a}}$ & $5.95^{\mathrm{b}}$ & $5.05^{\mathrm{ab}}$ \\
$\mathrm{F}_{6}$ & $5.20^{\mathrm{a}}$ & $4.75^{\mathrm{a}}$ & $5.05^{\mathrm{ab}}$ & $5.55^{\mathrm{b}}$ \\
\hline
\end{tabular}

Values followed by different alphabets show significantly different on Duncan test $(\alpha=0.05)$

Table 4 Friedman test of cassava and coconut waste flakes.

\begin{tabular}{lll}
\hline Formulation & Rate & Ranking \\
\hline $\mathrm{F}_{1}$ & 2.60 & 2 \\
$\mathrm{~F}_{2}$ & 2.95 & 3 \\
$\mathrm{~F}_{3}$ & 2.35 & 1 \\
$\mathrm{~F}_{4}$ & 4.15 & 4 \\
$\mathrm{~F}_{5}$ & 4.25 & 5 \\
$\mathrm{~F}_{6}$ & 4.70 & 6 \\
\hline
\end{tabular}


Table 5 Comparison of chemical and microbiological characteristics of control $\left(F_{1}\right)$ and the selected $\left(F_{3}\right)$ flakes.

\begin{tabular}{llll}
\hline No. & Parameter & $\mathrm{F}_{1}$ & $\mathrm{~F}_{3}$ \\
\hline 1 & Water (\%) & 2.54 & 2.52 \\
2 & Ash (\%) & 2.34 & 2.27 \\
3 & Fat (\%) & 10.06 & 14.40 \\
4 & Protein (\%) & 2.35 & 4.50 \\
5 & Carbohydrate (\%) & 82.71 & 76.31 \\
6 & Dietary fiber (\%) & 4.15 & 8.56 \\
7 & Gluten (ppm) & 0.0012 & 0.0042 \\
8 & K (ppm) & $2,160.42$ & $2,346.11$ \\
9 & Na (ppm) & $1,845.35$ & $2,163.66$ \\
10 & Fe (ppm) & $1,225.38$ & $1,415.42$ \\
11 & Ca (ppm) & 219.64 & 225.24 \\
12 & Mg (ppm) & $1,904.54$ & $1,996.45$ \\
13 & Total plate count (col/g) & $<10$ & $<10$ \\
14 & E. coli (col/g)* & $<3$ & $<3$ \\
15 & Mold (col/g) & 10 & $<10$ \\
16 & B. cereus (col/g) & 100 & $<100$ \\
\hline
\end{tabular}

$\mathrm{F}_{1}: 100 \%$ cassava flour, $0 \%$ coconut waste flour (control); $\mathrm{F}_{3}: 80 \%$ cassava flour, $20 \%$ coconut waste flour.

of foodstuffs. Thus, the chosen flakes $\left(\mathrm{F}_{3}\right)$ meet the requirements of SNI [17]. The fat content of $\mathrm{F}_{3}$ is higher than that of $\mathrm{F}_{1}$. It is because the coconut waste flour used (43.32\%) has a higher fat content than cassava flour does. Dietary fiber content of the selected flakes $\left(\mathrm{F}_{3}\right)$ is equal to $8.56 \%$, while the dietary fiber content of the standard flakes $\left(\mathrm{F}_{1}\right)$ is $4.15 \%$. In the microbiological analyses, TPC, E. coli, mold and $B$. cereus content in $F_{1}$ and $F_{3}$ are lower than SNI requirements. Besides, $\mathrm{F}_{3}$ has higher $\mathrm{K}, \mathrm{Na}, \mathrm{Ca}$ and $\mathrm{Mg}$ contents compared to $\mathrm{F}_{1}$ (control) and $\mathrm{F}_{3}$ is relatively rich in minerals. According to Alimentarius Codex [18], there are two food labels on gluten concentration: "gluten free" (below $20 \mathrm{ppm}$ ) and "very low gluten" (20-100 ppm). The result of gluten analysis is $0.0042 \mathrm{ppm}$. It means that cassava flakes do not contain gluten (gluten free).

\section{Conclusions}

Flakes made with $80 \%$ cassava flour and 20\% coconut waste flour $\left(\mathrm{F}_{3}\right)$ become the chosen product based on the organoleptic tests, including color, aroma, crispness and flavor parameters. The flakes are gluten free and have high dietary fiber contents, so they can serve as practical and nutritious ready-to-eat food.

\section{Acknowledgments}

Authors would like to thank Umar Bahari, Muthia Septiani and Andriani Pane for their contribution to this study and also give big gratitude to BP3ipteks, West Java for the grant given for this study.

\section{References}

[1] Djaafar, and Rahayu. 2003. Cassava and Its Products. Yogyakarta: Kanisius. (in Indonesian)

[2] Susanto, E. 2008. Cassava Flour and Its Products. Yogyakarta: Kanisius. (in Indonesian)

[3] Murtiningsih, and Suryanti. 2011. The Making of Flour of Tubers and the Product Variations. Jakarta: Agromedia Pustaka. (in Indonesian)

[4] Rukmana, I. 1997. Cassava, Cultivation and Post Harvest. Yogyakarta: Kanisius. (in Indonesian)

[5] Supriatna, D., Pohan, G., Suyacesa, Y., and Kusmayadi, D. 2012. Study of the Utilization of Highly Fibrous VCO-Waste Coconut Flour. Final Report, Center for Agro Industry, Bogor. (in Indonesian)

[6] Widiastuti, D., and Ade, H. M. 2015. "Characteristics of Traditional Market Waste Coconut Flour and VCO Waste Coconut Flour." Ekologia Journal 15 (1): 40-6. (in Indonesian)

[7] Indonesia National Standardization Agency (SNI). 1992. 
"Test Method for Foods and Beverages." SNI 01-2891-1992, Indonesian National Standard, Jakarta. (in Indonesian)

[8] Belitz, H. D., Grosch, W., and Schieberle, P. 2008. Food Chemistry, 4th ed.. Munchen, Germany: Springer.

[9] Association of Official Analytical Chemistry (AOAC). 1995. Official Methods of Analysis of the Association of Official Analytical Chemistry. Washington, D.C.: AOAC.

[10] Haraszi, R., Chassaigne, H., Maquet, A., and Ulbert, F. 2011. "Analytical Methods for Detection of Gluten in Food-Method Developments in Support of Food Labeling Legislation.” Journal of AOAC International 94 (4): 1006-25.

[11] International Standards Organization (ISO). 2003. "Horizontal Methods for the Enumeration of Microorganisms - Colony Count Technique at $30{ }^{\circ} \mathrm{C} . "$ Microbiology of Food and Animal Feeding Stuffs, ISO 4833: 2003, Geneva, Switzerland.

[12] Feng, P., Weagant, S. D., Grant, M. A., and Burkhardt, W. 2002. "Enumeration of Escherichia coli and the Coliform Bacteria." In Bacteriological Analytical Manual (BAM). US: Food and Drug Administration (FDA).
[13] Tournas, V., Stack, M. E., Mislivec, P. B., Koch, H. A., and Bandler, R. 2001. "Yeasts, Molds and Mycotoxins." In Bacteriological Analytical Manual (BAM). US: Food and Drug Administration (FDA).

[14] Winarno, F. G. 1992. Food Chemistry and Nutrition. Jakarta: PT Gramedia Pustaka Utama. (in Indonesian)

[15] Indonesia National Standardization Agency (SNI). 2006. "Wheat Flour." SNI 01-3751-2006, Jakarta.

[16] KURTZWEIL. 2002. "The $10 \%$ Solution for a Healthy Life: How to Eat." Accessed March 6, 2002. http://www.kurzweilai.net/the-10-solution-for-a-healthy-1 ife-chapter-6-how-to-eat.

[17] Indonesia National Standardization Agency (SNI). 1995. "The Quality Requirement of Instant Cereal Based Complementary Foods." SNI 01-3842-1995, Jakarta.

[18] Codex Alimentarius. 1981. "Standard for Processed Cereal-Based Foods for Infants and Young Children." Codex Stan 074-1981. Accesed January, 2006. http://www.fao.org/fao-who-codexalimentarius/sh-proxy/ en/?lnk=1\&url=https $\% 253 \mathrm{~A} \% 252 \mathrm{~F} \% 252 \mathrm{Fworkspace}$.fao .org\%252Fsites $\% 252$ Fcodex $\% 252$ FStandards $\% 252 \mathrm{FCO}$ DEX\%2BSTAN\%2B74-1981\%252FCXS_074e.pdf. 